\section{A publicidade como o teatro do Estado moderno}

BOURDIEU, Pierre. Sobre o Estado: Cursos no Collège de France (1989-1992). Trad. Rosa Freire d'Aguiar. São Paulo, Companhia das Letras, 2014. 573 páginas.

\section{Paula Montero}

Os editores Patrick Champagne, Remi Lenoir, Franck Poupeau e Marie-Christine Rivière, que se propuseram a empreender a árdua tarefa de reunir, transcrever e editar os cursos proferidos por Pierre Bourdieu no Collège de France entre dezembro de 1989 e dezembro de 1991, são grandes conhecedores da extensa obra desse autor e lhe dedicaram grande parte de sua energia intelectual. Por terem convivido e participado intimamente de seu círculo intelectual - Champagne e Lenoir colaboraram na pesquisa que resultou no livro Misères Du Monde de 1993, Poupeau foi seu aluno de doutorado e Marie-Christine-Rivière, secretária da revista Actes de La Recherche em Science Sociales, publicou em 2002, com Yvette Delsaut, uma bibliografia completa de seus trabalhos - conhecem profundamente seu pensamento e contribuíram de várias maneiras para sua divulgação. Essa qualidade dos editores lhes conferiu, sem dúvida, uma posição privilegiada para que pudessem alcançar o objetivo a que se propuseram na obra comentada: o de conciliar a fidelidade ao pensamento de Bourdieu com a garantia de legibilidade que uma transcrição relativamente literal de suas aulas não favorece. Essa tensão entre a ordem de um raciocínio bem amarrado e a associação relativamente livre do pensamento confere à obra em questáo uma personalidade bastante particular. Embora os editores tenham procurado organizar o texto em subtítulos temáticos, o pensamento escapa continuamente dessa estrutura ganhando a fluidez de uma reflexão em processo. Esse efeito, em parte tributário da situação de comunicação direta com sua audiência em sala de aula, nos traz pequenas e agradáveis surpresas ao longo da leitura. Seus comentários sobre o trabalho do construtivista Gunsfield, por exemplo, esclarecem como ele inspira seu conceito de eficácia simbólica e, ao mesmo tempo, sua crítica ao conceito de Estado desse autor - enquanto lugar (neutro) da luta entre os pontos de vista - torna mais claro para o leitor os caminhos que Bourdieu toma para construir sua própria posição sobre o tema. Essas inspiraçóes teóricas nem sempre estão claras nos trabalhos mais acabados de Bourdieu. Além disso, vez por outra, emerge no texto da obra um tom mais coloquial que denuncia suas hesitaçóes e incertezas quando, por exemplo, confessa a seus alunos que, embora tentasse lhes transmitir ideias novas, é acometido pela sensação constante de repetir trivialidades ou reiterar ideias que já foram ditas centenas de vezes.

Em razão dessas características, não se pode esperar do livro, apesar de seu título, uma teoria organizada sobre o Estado. $\mathrm{Na}$ verdade, os próprios editores mencionam o aparecimento tardio dessa palavra na obra do autor que, até o final da década de 1980, preferia tratar o problema dos campos de poder em termos de classes dominantes e discursos de autoridade. Nos cursos aqui editados, o tema do Estado ganha centralidade não tanto como um objeto teórico em si mesmo, mas, sim, como o resultado de suas pesquisas anteriores. Seu interesse pelo Estado emergiu, segundo os editores, como decorrência do desenvolvimento de sua teoria geral do espaço social, ela mesma resultado da acumulação progressiva de conhecimento sobre o funcionamento empírico dos mais diversos campos - universitário, literário, patronal, religioso, jurídico etc. - que ele estudara sucessivamente ao longo década de 1980. A questão do Estado emerge para Bourdieu como problema quando ele começa a se interrogar a respeito das relaçôes entre os diferentes campos. Em um primeiro movimento reflexivo, Bourdieu faz um balanço crítico dos modelos historiográficos que procuram enfrentar o problema da passagem do Estado dinástico ao Estado moderno; em um segundo movimento, procura definir o Estado como um metacampo resultante dos processos históricos de diferenciação e concorrência entre diferentes campos (jurídico, administrativo, intelectual, político etc.).

Ao abordar o Estado como um campo de poder, Bourdieu privilegia uma análise em que a competição entre os campos pela apropriação do poder econômico e estatal ocupa todo o espectro da política. Seu esforço visa demonstrar "a que ponto as sociedades diferenciadas são penetradas de um extremo ao outro pela lógica estatal" (p. 401). Nesse senti- 
do, sua ideia de público acaba por ficar inteiramente subsumida às lutas entre os campos pensados implicitamente como vinculados de um modo ou de outro à lógica da burocracia estatal. Em sua aula de novembro de 1991, faz uma crítica explícita ao conceito habermasiano de espaço público, "conceito detestável que nos vem da Alemanha", deixando impensado esse espaço social intermediário entre a intimidade e a esfera estatal. Em seu esforço de pensar o Estado como metapoder que estrutura e determina todos os campos, Bourdieu reduz a fala pública ao teatro do Estado que se dá em espetáculo para existir por meio de uma liturgia cívica.

Com todas as virtudes de uma obra que desafia as interpretaçóes clássicas sobre a emergência do Estado moderno e suas formas contemporâneas de funcionamento, Sobre o Estado. Cursos no Collège de France (1989-1992) é também valioso pelas reflexôes que arrisca sobre a função intelectual e suas dificuldades. Para Bourdieu, pensar sociologicamente o Estado é construir um ponto de vista que se afaste, ao mesmo tempo, da pretensão (um pouco louca, segundo ele) de produzir uma teoria geral vazia e dos limites impostos pelos pontos de partida empíricos demasiadamente particulares e específicos. Pensar com os clássicos significa buscar neles instrumentos heurísticos e lições a tirar de seus erros e falhas metodológicas. E ensinar significa evitar a pretensão de dizer a verdade sobre o mundo social. Sobre o Estado... não é, por todas essas razóes, nem uma obra acabada, nem uma obra linear. É um livro no qual o autor aparece com suas dúvidas e hesitaçóes. É um livro em que a função de mestre emerge na plenitude de seu diálogo com a audiência que procura seduzir e convencer: seus alunos.

PAULA MONTERO é professora titular da Universidade de São Paulo (USP), coordenadora adjunta da Fundaçáo de Amparo à Pesquisa do Estado de Sáo Paulo (Fapesp) e pesquisadora do Centro Brasileiro de Análise e Planejamento (Cebrap). E-mail: pmontero@usp.br. 